\title{
AN ANALYSIS OF SOCIO ECONOMIC CONDITION OF WOMEN ENTREPRENEURS - With Special Reference to Mysore District
}

\author{
Dr.R.H.PAVITHRA \\ Assistant Professor, Department of Economics, \\ Karnataka State Open University, Muktha Gangotri, Mysore -570006
}

\begin{abstract}
Entrepreneurship has taken on special significance in the context of Indian economic growth in a rapidly changing socioeconomic and political environment, particularly in the industrial sector. In today's world of privatisation, liberalisation, and globalisation, entrepreneurs are responsible for development. Entrepreneurship is a human act of creativity. As a result, entrepreneurship helps to increase per capita income, standard of living, and capital formation in the country's poorest regions. It is a process that covers risk, uncertainty, innovation, planning, and decision-making in order to accelerate economic growth. Here, in the research paper, a field-based picture of women entrepreneurship in Mysore district of Karnataka is presented analyzing their various socio-economic statuses through a structured questionnaire.
\end{abstract}

Key words: Women, Entrepreneurship, Growth, Development, Income.

\section{INTRODUCTION}

Entrepreneurship, which comes under the umbrella of the business regime, which plays a major role in the development of the country and its economy in a fruitful condition by setting up of organizations, may be small or large in size of operation. These are the individuals who have the necessary skills and knowledge to enter into a business in order to acquire a market with high potential decision making and thus catch-up on profit. Nowadays, the government is also encouraging entrepreneurship, resulting in improved economic conditions and the abolition of poverty through job creation. Government banks are providing financial assistance to young women through their programs like start-up India, MUDRA yojana scheme for women, stree Shakti package for women entrepreneurs, Annapurna scheme, mahila udyami nidhi scheme, bharatiya mahila bank business loan etc. The objective of this study was to learn how women's entrepreneurship is increasing in India because of government help and to use this information to inspire other women to come up with their own dreams and ideas to become entrepreneurs using the available resources. Technically, women entrepreneurship is nothing but women who manage and organize the organization with successful decisions by handling the uncertain risks that may occur in the future. Here the paper is prepared to provide knowledge about women entrepreneurs and the kind of support from the government of India and from Indian banks. The data has been collected from websites and articles. This study is an attempt to make awareness of challenges faced by successful women entrepreneurs and government assistance to achieve progress.

\section{REVIEW OF LITERATURE}

Ms.Yogitha Sharma (2013), this study investigated the challenges that women face when attempting to become entrepreneurs, as well as the assistance and measures provided by the government. Finally, proper utilisation of government assistance will lead to economic development.

Vinothalakshmi J.; Ganesan, R. (2013) has expressed the other sides of Indian Women's entrepreneurship is a new phenomenon that is causing a slew of issues. In India, the rise of female entrepreneurs and their contribution to the national economy is palpable. Women entrepreneurs are defined by the government of India based on their participation in equity and employment in a business enterprise. Women form the family, which leads to society and family. Women's social and economic development is critical to the development of any country. The study's goal is to figure out what's wrong Lalitha Iyer's study (1991) on "Women Entrepreneurs Challenges and Strategies" analyses major constraints faced by women entrepreneurs and reflects upon specific policies and programmes for women entrepreneurship development Angayarkanni (2010) According to her research on "Problems of Women Entrepreneurs in India," equality in education is the key to meeting other requirements for a culture of peace. Women's economic empowerment and entrepreneurship 


\section{DOI: 10.17148/IARJSET.2021.8704}

continue to be hampered. Discrimination in education, training, hiring, credit, the right to own and inherit property, lower pay, promotion for equal work, and greater domestic responsibilities for women are among the obstacles.

Dr. Rana Zehra Masood (2011) in his study "Emergence of women-owned companies in India, an insight" he revealed that India is the dominant male society and that both economically and socially, women are considered to be dependent on men. The total dependency of high group middle class women seems to be diluted, as they are more conscious of their individual needs and are calling for greater equality.

\section{OBJECTIVES}

* To analyse the socio economic condition of women entrepreneurship in case study area

* To examine the role of government in encouraging women entrepreneurship

* To suggest suitable measures to improve their socio economic condition in study area

\section{METHODOLOGY}

The present study examines socio-economic condition of women entrepreneurship in Mysore district. The present study has been carried out only in five taluks of Mysore district. Those taluks are K.R.Nagar, Hunsur, T.Narasipura, Periyapatana, and Nanganagud taluks of Mysore district of Karnataka state. The present study is based on the primary as well as secondary data. 40 respondents from each taluk has considered on random sample basis. Totally 200 respondents are considered for the present case study. Simple percentage method is used for analysis.

\section{DATA ANALYSIS AND INTERPRETATION}

Table 1: Age Composition

\begin{tabular}{|l|c|c|}
\hline \multicolumn{1}{|c|}{ Age Group } & Respondents & Percentage \\
\hline $18-30$ & 70 & 35 \\
\hline $31-50$ & 80 & 40 \\
\hline Above 50 & 50 & 25 \\
\hline Total & 200 & 100 \\
\hline
\end{tabular}

Source: Field Survey

Table 1 reveals that 70 (35\%) respondents belong to the age group of 18-30 years, majority of 80 (40\%) respondents comes under the age group of 31- 50 years and around 50 (25\%) respondents are above 50 years of age.

Table 2: Reason for Starting up Business

\begin{tabular}{|l|c|c|}
\hline \multicolumn{1}{|c|}{ Reasons } & Respondents & Percentage \\
\hline For economic needs & 120 & 60 \\
\hline To be independent & 46 & 23 \\
\hline To support for family & 34 & 17 \\
\hline Total & 200 & 100 \\
\hline
\end{tabular}

Source: Field Survey

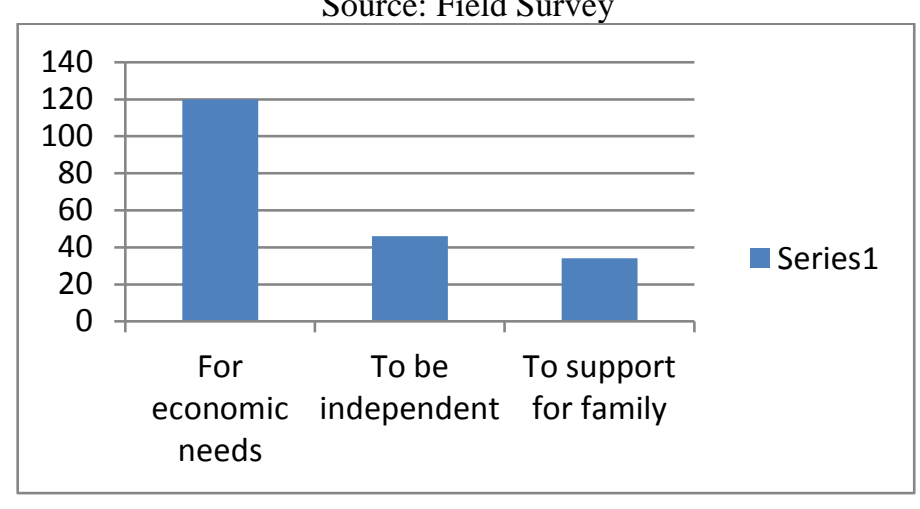

Table 2 explains that $120(60 \%)$ respondents have started up their business for their financial requirement, followed by $46(23 \%)$ respondents who have started their job due to be more economically and socially independent and around 34 (17\%) respondents have entered this profession to support their family. 
International Advanced Research Journal in Science, Engineering and Technology

Vol. 8, Issue 7, July 2021

DOI: 10.17148/IARJSET.2021.8704

Table 3: Problems faced during starting up of business

\begin{tabular}{|l|c|c|}
\hline \multicolumn{1}{|c|}{ Problem faced } & Respondents & Percentage \\
\hline Lack of fund & 100 & 50 \\
\hline Lack of family support & 40 & 20 \\
\hline Lack of experience & 40 & 20 \\
\hline Lack of skill & 20 & 10 \\
\hline Total & 200 & 100 \\
\hline
\end{tabular}

Source: Field Survey

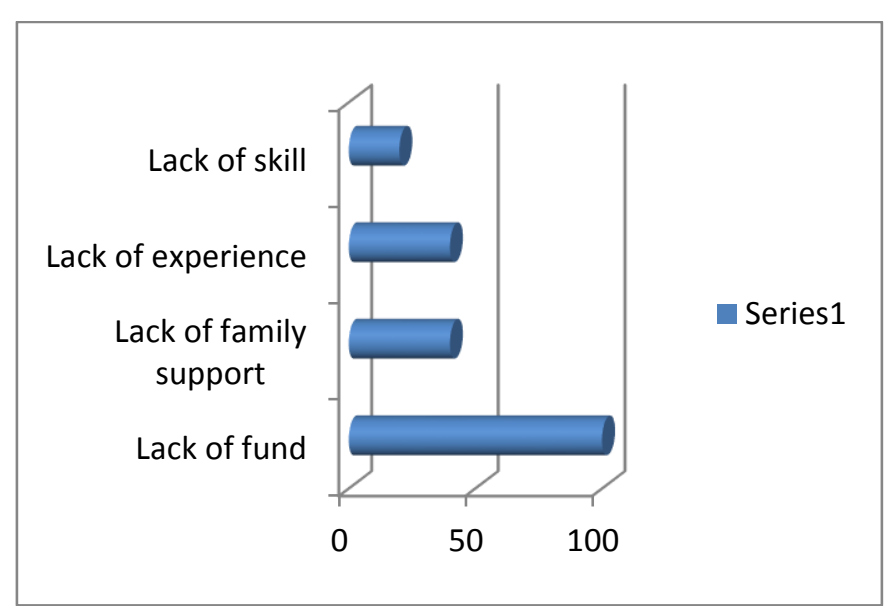

Table 3 highlights $100(50 \%)$ respondents have expressed that lack of finance is the major hindrance to start their business, followed by $40(20 \%)$ respondents who have expressed that there is no family support and the same percentage of respondents have said lack of experience have made them fear to start as entrepreneurs and around 20 (10\%) respondents have revealed that lack of skill is another problem faced by these respondents in the due course of starting up their entered this profession to support their family.

Table 4: Financial Source for Starting Business

\begin{tabular}{|l|c|c|}
\hline Sources & Respondents & Percentage \\
\hline Banks & 90 & 45 \\
\hline Savings & 70 & 35 \\
\hline $\begin{array}{l}\text { Non-institutional like } \\
\text { friends and relatives }\end{array}$ & 40 & 20 \\
\hline Total & 200 & 100 \\
\hline
\end{tabular}

Source: Field Survey 


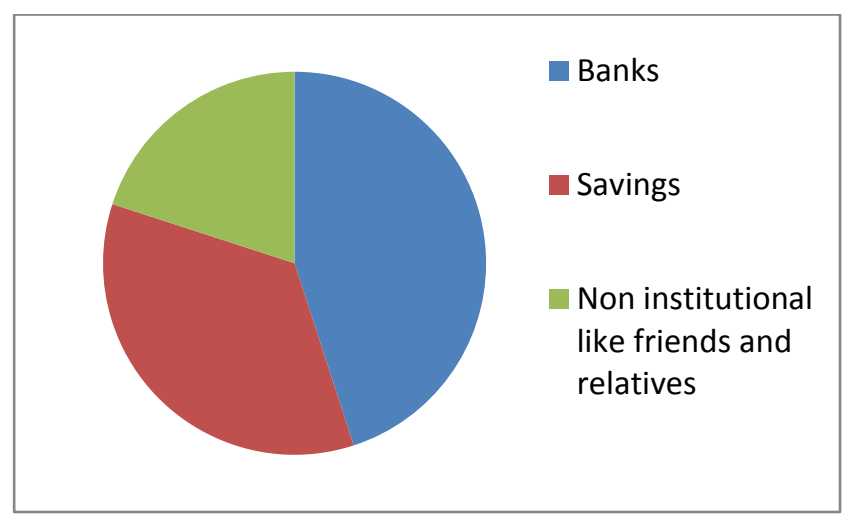

Table 4 explains that 90(45\%) respondents have expressed that they get financial sources from institutional agencies especially by banks, 70 (35\%) respondents said mainly by their savings, 40 (20\%) respondents revealed that they borrow from their friends and relatives.

Table 5: Payment mode by Customers

\begin{tabular}{|l|c|c|}
\hline Mode of Payment & Respondents & Percentage \\
\hline Cash & 136 & 68 \\
\hline Credit & 64 & 32 \\
\hline Total & 200 & 100 \\
\hline
\end{tabular}

Source: Field Survey

Table 5 expresses that $136(68 \%)$ respondents said that mode of payment will be in the form of cash but 64 (32\%) said that they get in the form of credit.

Table 6: Government's Role towards encouraging women to start up Entrepreneurship

\begin{tabular}{|l|c|c|}
\hline Programmes & Respondents & Percentage \\
\hline $\begin{array}{l}\text { Loans at lower rate of } \\
\text { interest }\end{array}$ & 92 & 46 \\
\hline Training at regional level & 70 & 35 \\
\hline $\begin{array}{l}\text { Programmes like Udyogini, } \\
\text { swawalamban, Mudra etc, }\end{array}$ & 38 & 19 \\
\hline Total & 200 & 100 \\
\hline
\end{tabular}

Source: Field Survey

Table 6 explains that $92(46 \%$ ) respondents have expressed that they would be more benefited if government provides financial sources at low rate of interest, 70 (35\%) respondents revealed that training should be provided at regional level, $38(19 \%)$ respondents explained that programmes like Udyogini, Swawalamban, Mudra should be made more reachable to all women of interior villages.

\section{FINDINGS}

- A large number of respondents belong to the age group of 31-50 years.

- The majority of the respondents opined that they have started as entrepreneurs mainly because of financial need.

- Around 100 respondents said that the major hindrance was lack of funds to start business.

- Many respondents said that their major source of finance is from banks.

- 136 respondents explained that the mode of payment would be in the form of cash rather than credit.

- The majority of the respondents are of the opinion that the government should provide financial assistance at a lower cost of interest.

\section{SUGGESTIONS}

- Proper and effective training should be provided for women.

- To become aware of the government's programmes for women's welfare, education is needed.

- Loans should be provided at a lower rate of interest.

- Women from economically disadvantaged backgrounds must be given soft loans and subsidies. 


\section{International Advanced Research Journal in Science, Engineering and Technology}

Vol. 8, Issue 7, July 2021

\section{DOI: 10.17148/IARJSET.2021.8704}

- The government must set up exhibition stalls in rural areas to promote the selling of their goods.

- A large number of IIT diploma courses in rural areas provide training cum production workshops.

- Language-based classes must be developed in regional areas to improve communication, which will aid in the sale of their goods.

- NGO's should tie up with the government to provide training and install sales cum exhibitions.

\section{CONCLUSION}

Women are very interested in education and improving their personal skills and competencies, which gives the government opportunities to develop new policies to improve their socioeconomic situation. Proper education and training courses for women are required to accelerate the empowerment process. Training in multidisciplinary functions in rural areas can help to improve the overall condition of women entrepreneurs.

\section{REFERENCES}

1. Sharma Yogita (2013): Women Entrepreneur in India, IOSR Journal of Business and Management (IOSR-JBM), e-ISSN: 2278-487X, p-ISSN: 23197668. Vol-15, Issue 3, (PP-9-14)

2. Nikhat Tabasum; B S Hugar. "Gender Differences Pertaining To Work-Life Balance". International Research Journal on Advanced Science Hub, 2 , Special Issue ICARD 2020, 2020, 187-192. doi: 10.47392/irjash.2020.117

3. Anuradha N. Yadav. "Maternity Wear Solution for Rural and Urban Area Women". International Research Journal on Advanced Science Hub, 2 , Special Issue ICARD 2020, 2020, 159-162. doi: 10.47392/irjash.2020.112

4. Poornima S V. "An Invogue Myth of Dear Brutus". International Research Journal on Advanced Science Hub, 2, Special Issue ICIES 9S, 2020, 7073. doi: $10.47392 /$ irjash.2020.162

5. Vinothalakshmi J. \&Ganesan, R. (2013): Problems and Prospects of Women Entrepreneurship, Asia Pacific Journal of Management \& Entrepreneurship Research, (pp-16-23)

6. Lalitha, I. (1991), Women entrepreneur's challenges and strategies, Frederich, Ebert Stiftung, New Delhi

7. Shangrella M K Rajesh. "Rediscovery of handloom cluster with reference to sustainability and empowerment". International Research Journal on Advanced Science Hub, 2, Special Issue ICSTM 12S, 2020, 116-120. doi: 10.47392/irjash.2020.272

8. Angayarkanni, "Problems of Women entrepreneurs in India", Southern Economist, February, 2010, Vol.48, No.19, pp, 44-46

9. Dr Rana Zehra Masood, "Emergence to women-owned businesses in Indian insight", 2011

10. Ms. Ritu; Preeti Chawla. "Indian Environment for Entrepreneurship: A Study based on Literature Review". International Research Journal on Advanced Science Hub, 3, Special Issue ICIES-2021 4S, 2021, 18-21. doi: 10.47392/irjash.2021.104 